\title{
Demographic ageing in the old industrial regions - specifics and links on the example of the Ústí nad Labem Region (N Czechia)
}

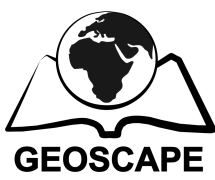

\author{
Petr Kačírek ${ }^{1 *}$ \\ ${ }^{1}$ Department of Regional Development and Public \\ Administration, Faculty of Social and Economic Studies, \\ J. E.Purkyne University, Moskevská 54, 40096 Ústí nad Labem, \\ Czech Republic \\ *petr.kacirek@osu.cz
}

\begin{abstract}
Through this paper, the author would like to raise a discussion on possible specific effects of current demographic trends (namely the demographic ageing) in low-performace regions of Central and Eastern Europe. The article focuses on the current tendencies of the demographic development of the Ústí nad Labem Region (N Czechia), an old industrial region undergoing the economic transition since 1990s. The demographic development in the Ústí nad Labem Region is put in the context of the demographic development of the world, Europe, and the Czech Republic. Population development in the Ústí nad Labem Region copies the tendencies at the level of the territorial units of higher level. The differences in values of the demographic indicators, especially when compared to the Czech Republic, are mainly caused by specific demographic, economic, and social structures of the inhabitants of the region. The most important and discussed tendency of the population development in last decades is the process of the demographic ageing. The change will be slow but growing stronger with the ageing process becoming more powerful. It would be necessary to prepare for the process, particularly in the economic and social field, at the level of the regional government, otherwise the demographic ageing may further restrict the speed of economic and social transition in the region.
\end{abstract}

Key words: Demographic development; Demographic aging; Transition; Ústí nad Labem Region

Highlights for public administration, management and planning:

- possible impacts of demographical ageing on labour force in a restructuring old industrial region are analysed

- although the speed of demographical ageing is not high, its further progress may the demographic ageing may further restrict the economic and social transition in the region

Received: 2 May 2015 - Received in revised form: 16 Jun 2015 - Accepted: 19 Jun 2015

\section{Introduction}

The demographic ageing is now part of the population development of most of the countries of the world (e.g., Warnes 1993; Pavlík 2004; Muenz 2007; Bremner et al. 2009; Walker,
Maltby 2012; United Nations 2015). As noted by Walker and Maltby (2012), "the ageing of European countries has widespread implications for current and future social and economic policies across the region". 
From the demographic point of view, the world population could be divided into two basic groups, which are the demographically developed and demographically lagging countries. The first group is characterized by the acceleration of the absolute and relative demographic ageing to a certain extent. These are the countries of the world where the first phases of the demographic revolution ended before the WWII. The conditions of development of the demographic revolution should be sought in the system of the global revolution of the modern age of which part it is, and explainable only within its context (Pavlík 2004). Within the demographically developed countries, and in Western European countries in particular, the current trend in population development is often described as the second demographical transition (SDT; Lesthaeghe, van de Kaa 1986; van de Kaa 1987), although current writing emphasize the variability in implications of this concept in different countries (e.g., Sobotka 2008). Generally, the concept stresses the importance of ideational changes in demographic behaviours in postmaterialistic (post-industrial societies). Since the 1990s, the process has entered the postcommunist Central and Eastern European Countries (Hoff 2011), where the political, economic and societal transition resulted in a change of both demographic behaviours and population structure in terms of both demographical indicators and spatial organization (cf. Turok, Mykhnenko 2007). Together with Western European countries and other developed countries of the world, the demographic ageing has therefore become a key issue in social policies of these countries. However, it must be emphasized that effects of demographic ageing on social welfare, economic performance and overall quality of life will be dependent on starting socio-economic and political conditions of the individual regions.

Although the demographic ageing and its effects on social welfare at a country level is a well established issue in current research (e.g., Rabušic 1995; Fiala, Langhamrová 2007; Holmerová et al. 2011), its regional differences and effects corresponding to differing situation and demands in particular regions was only rarely encountered. Among the regions in Central and Eastern Europe that might be specifically affected by demographic ageing are those that still did not overcome former social and economic burdens; primarily the structurally affected old industrial regions.

Through this paper, the author would like to raise a discussion on possible specific effects of current demographic trends (namely the demographic ageing) in low-performance regions of Central and Eastern Europe on the example of the Ústí nad Labem region (Balej et al. 2008; Koutský et al. 2010; Hlaváček 2013). As a starting point of this discussion, the goal of the paper is to encompass the basic tendencies of the demographic development of the Ústí nad Labem Region and definition of the main determinants of the specific position of the region within the Czech Republic. The population development of the region is put in the framework of the theory of demographic revolution and the second demographic transition. From the territorial point of view, the analysis proceeds systematically from the world level to the territorial units of lower order.

\section{International and national context}

\subsection{Development of world population}

From the point of view of the population reproduction, significant decrease of the birth rate and death rate was reported during a relatively short time during the demographic revolution, hence the change to the character of the demographic reproduction from the extensive to the intensive forms, and ageing of the population. At present, the developed countries are now in the next phase of the changes to the character of the reproduction called the second demographic transition with low birth rates, usually under the limits of the simple reproduction, and improving death rates. The reduced intensity of the death rates occurs especially at high and very high age. The intensity of child mortality is so low that further reduction is negligible from the point of its impact on the death rates level. For the future, the basic trend 
is growing share and high number of old and very old people in the population, and that cardinal question is finding the position of these people in the society. The second group of the lagging countries hasn't finished the transition of the reproduction character due to different conditions of the origin of the demographic revolution, and the group is characterized by higher birth and death rates. Compared to the developed countries, the ageing of the population is not the question here but the population growth still continues despite the general trend of natural change. Naturally, it should be mentioned that the division of the population of the world into 2 groups is the generalization, and there are some variability within each group which is obvious when looking at the demographic indicators such as life expectancy and the general fertility and some others in the countries of the world.

The demographic ageing is historically unprecedented and non-returnable phenomena resulting in the essential change of the age structures of the world populations during the 21st century. In many countries, the population will not only grow old but decrease as well. This is also the perspective of Europe, and especially of the European Union of which population gets older and start decrease after the 2025 (Rychtaříková 2006).

The feature of the world population is it unbalanced distribution among the regions, world areas, countries, as well as in their borders. Similar situation could be seen in the demographic reproduction where different countries differ significantly. But while for the distribution of the population, which was always unbalanced, we can see the tendencies for increased differences in the population density of various areas (higher concentration to the cities and centres of so-called economic and political development), the development reproduction nature is dependent on the period in which the differences are seen, i.e. on the stage of the demographic development that continuously occurs for each population within them. The basic tendency is opposite to the development of the distribution of population; it is successive mutual adaptation of the birth and death rates level following the periods of important changes, which occur in all areas where people live and they mean a temporary differentiation of the level of these processes (Pavlík 2007). Data for the areas and countries of the world demonstrate the tendency of re-approaching of the birth and death rate levels.

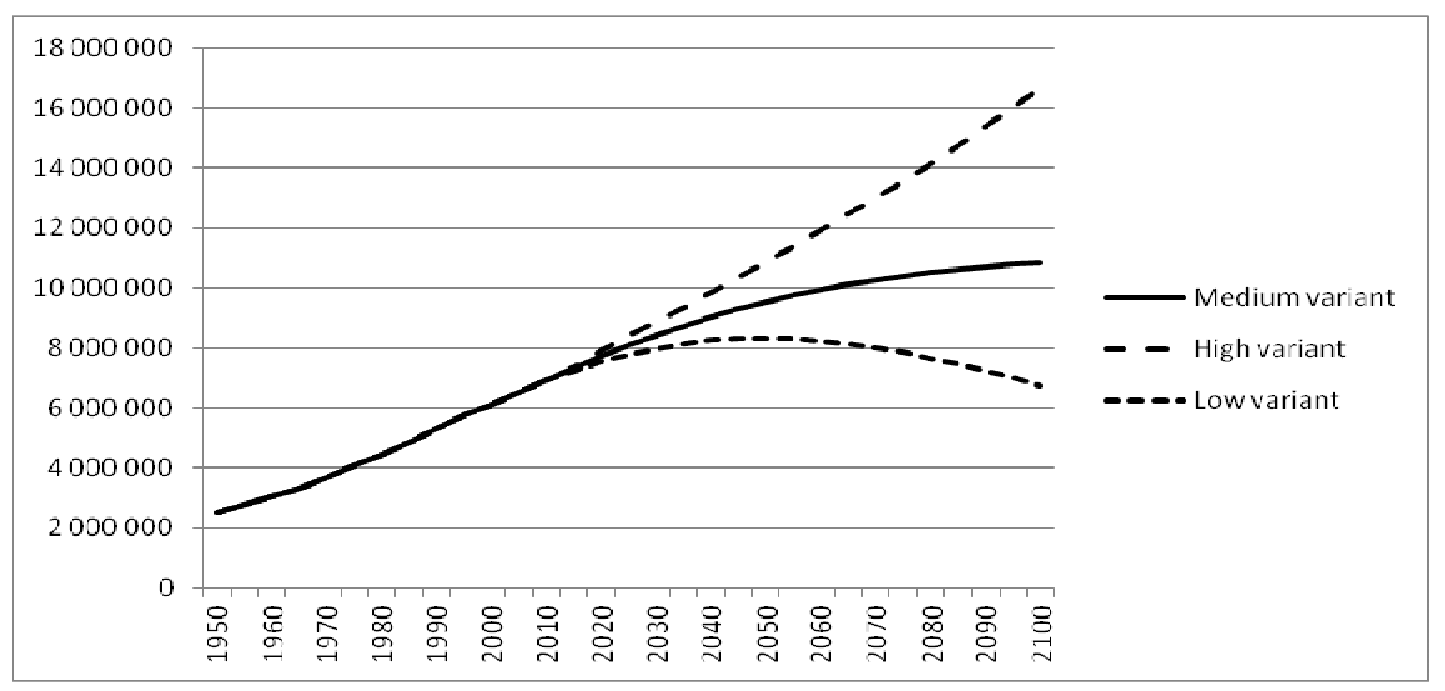

Fig. 1 - Development of World population (in thousands). Source: Population Division of the Department of Economic and Social Affairs of the United Nations Secretariat, World Population Prospects: The 2012 Revision, http://esa.un.org/unpd/wpp/index.htm 


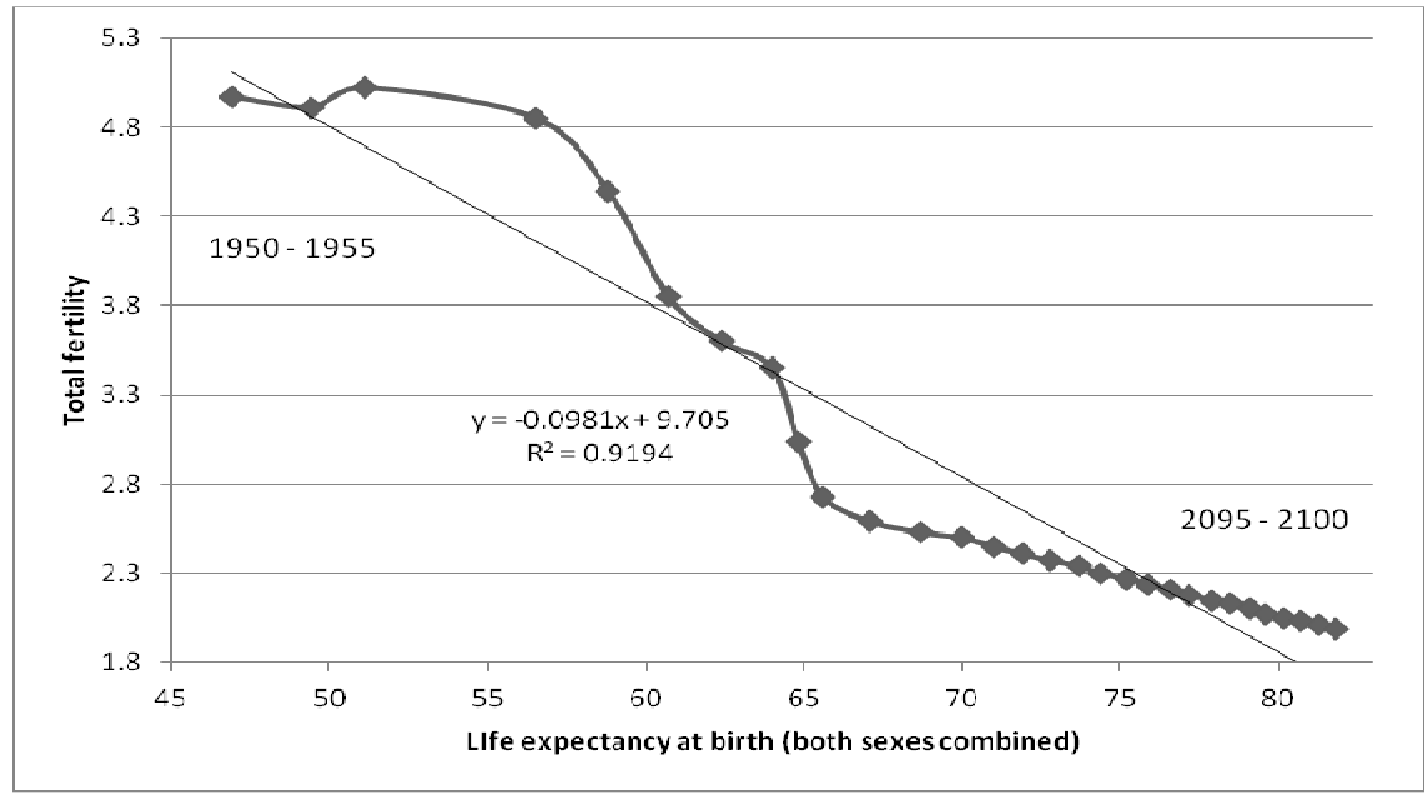

Fig. 2 - Development of World population - Total fertility and Life expectancy at birth (both sexes combined), Medium variant 1950 - 2100. Source: Population Division of the Department of Economic and Social Affairs of the United Nations Secretariat, World Population Prospects: The 2012 Revision, http://esa.un.org/unpd/wpp/index.htm

The population scientists model the future development of the population of the world especially with the use of the population prognosis attempting to reach the most precise estimate of the number and structure of the population (Fig. 1 and 2). Despite the results of the estimates may not be overpriced (particularly of the long-term ones), it is highly likely based on knowledge of the general regularities and natural relations of the population development then the population of the world copies the logistic curve and now, the population is behind it inflex point. Should the cause of the demographic revolution be given by the combination of many factors, the impact of the demographic development on the social and economic development is also the matter specific for each country in many aspects; for example, it depends on the economic development of the country, social values, legislation in the social fields, the level of health and social care, and more. The fears of the population increase is successively shifted by the fear of getting older, which is especially a hot issue for the countries that have already went through the demographic revolution, with high life expectancy, and the birth rate level is on or under the level of the simple reproduction.

\subsection{Development of the Czech population}

The one of the important fields of the study of the demographic ageing is the research of the impact of the demographic ageing on the economic and social development of the society, especially in the field of the economy, pension system, and healthcare. Should the cause of the demographic revolution be given by the combination of many factors, the impact of the demographic development on the social and economic development is also the matter specific for each country in many aspects; for example, it depends on the economic development of the country, the latest economic development, openness of the economy, current trends, legislation in the field of the social security, the level of health and social care, healthcare spending, and more. 
Over about last 20 years, which means during rather short time, the Czech Republic has to seen important changes in the demographic reproduction of the population resulting in successive acceleration of the demographic ageing process in the following decades of the 21st century (Fig. 3). From the ageing point of view, the main trends may be the successive increase of the life expectancy and a number of born children. From the point of demographically developed countries view, this is not any drama because the population of the Czech Republic copies with some delay the similar trend in the countries of the Western, Northern, and Southern Europe in the past decades. This is the continuance of the demographic revolution, or its next phase identified as the second demographic transition. The main feature of the second demographic transition is the drop of the general birth rate in long term fewer than 2.1 children per woman, i.e. under the limit of the simple reproduction. The birth rate drop is accompanied by the increasing age of mother upon delivery and the first delivery, and the increasing share of extramarital children. According to the records, more than $40 \%$ children are born out of the marriage in the Czech Republic but this number also includes children born to pairs that did not entered marriage formally.

In most countries of Europe, including the Czech Republic, the process of demographic ageing occurs. In the 1990s, the Czech Republic was characterized by accelerated ageing process, especially as consequence of drop in number of born children and shift of the numerically stronger generations born during the WWII and in the post-war era, and in the middle of the 1970 s to higher age. Changes to the death rate had double impact on the age structure and age of the society. On the first side the ageing process strengthened by reducing the intensity of the death rate in the middle and higher age and on the other hand, reduction of the death rate made the population younger. It was caused by the drop of the child mortality when increasingly higher share of born children survived the age of higher intensity of death rate after birth and then, it survived until the reproduction age. This process of getting the population younger was not extraordinarily dramatic thanks to the birth rate drop but its existence must be noted.

Prague and Central Bohemian Region clearly dominate in the population growth over the other regions; the growth of Central Bohemian Region is caused its function as a background for Prague and they together produce the most migration attractive region in the Czech Republic, this is in relation with the analysis of the economic growth in regions in the Czech Republic (Hlaváček 2013).

\section{The case of the Ústí nad Labem region}

The basic demographic structures include the age structure of the population that significantly influences the demographic processes. One of the indicators of the age structure is "average age" used to measure the process of the demographic ageing and compare age of different populations. It is weighted arithmetic average of life in years lived out by members of the population, and the weights are the number of members of each age units alive. For all regions of the Czech Republic, the values of this indicator indicate the demographic ageing process. Compared to the Ústí nad Labem Region, the population of the Czech Republic is older and the position does not change. This is caused by similar reaction of the population to the change to political and economic conditions after 1989 subsequently reflected in different areas of life of both populations, and results in similar patterns of the reproduction behaviour where the differences are given particularly by the underlying structure of the population. Current average age of the Ústí nad Labem Region is just the base for further population development, and therefore development of the age structure. The ageing process will continue both in the Czech Republic as well as in most demographically (and economically) developed countries of Europe (Kačírek 2001, 2003). It will not get round the Ústí nad Labem Region and the process should be considered when thinking about reflections and prognoses that employ the age structure of the population. From the point of view of the 
demographic theory, the long-term aspects may assume reduction of the inter-regional differences not as far as the age structure is concerned but in relation with the other demographic processes, and convergence of the reproduction behaviour of the population in the Ústí nad Labem Region and the Czech Republic.

From the birth rate point of view, the phenomena of year-to-year decrease in the birth rate within the population development of the Czech Republic have been registered since 1980s. An important milestone for the birth rate in the Czech Republic was the first half of 1990s where for the very first time in the history of the statistical monitoring the number of new born children dropped under 90 thousands. The root case was change to the political situation, the new economic possibilities, as well as the new social situation for many people associated with the new opportunities as well as threats. Similarly to the Czech Republic, the Ústí nad Labem Region recorded significant drop in the birth rate after 1989. The birth rate drop culminated late in the 1990s and early in the 2000s, and the total birth rate dropped in both territorial units at roughly identical pace, which demonstrates similar behaviour of the population in the birth rate area.
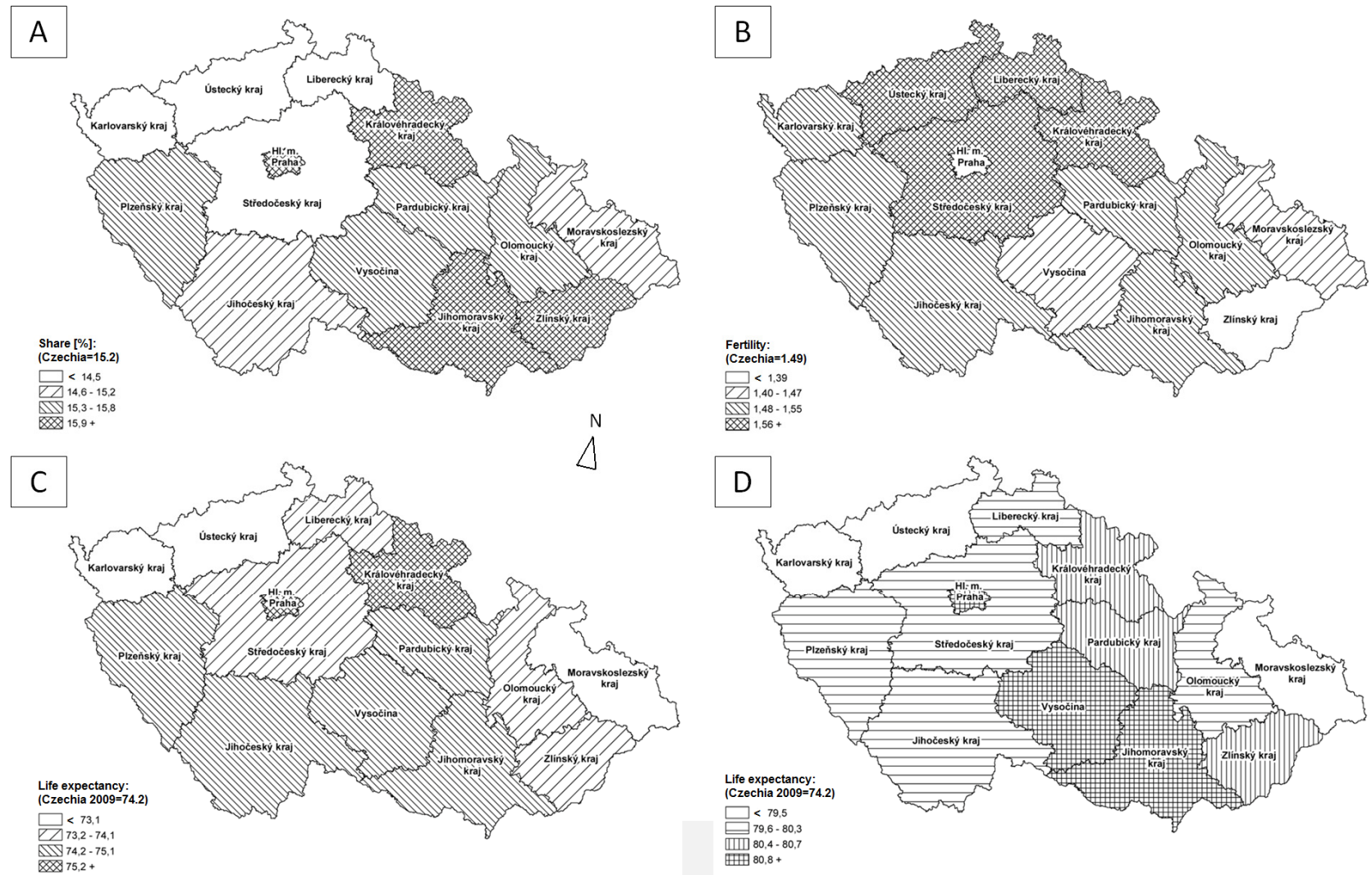

Fig. 3 A - Share of 65+ years on total population (31st December, 2009). B - Fertility rate in 2009. C - Life expectancy of men in 2009 and D - life expectancy of women in 2009. Source: CZSO (2014a, 2014b, 2014c)

At the same time average age of mothers upon delivery and the first delivery increased, and the number of extramarital children increased as well. The share of extramarital children is, however, influenced by the growing interest, particularly of young people, in modern form of unmarried living. According to the results of the last census, this form of living is widely used in the Ústí nad Labem Region and at the same time, the number of extramarital children is born here. 
Another difference in the birth rate structure is higher age of the mothers upon first delivery in the Czech Republic and earlier retained birth rate of the population-strong age group of the 1970s in the Ústí nad Labem Region. The principal change with respect to the reproduction of both populations is the shift in age of maximum fertility intensity from age group 20-24 years to the age group 25-29 for women, and significant increase of share of the group 30-34 years. Beginning of the 21st century is characterized by increase of the total fertility with respect to the transition of population-stronger age groups of women to the age of maximum fertility intensity. Despite the growth of number of born children, the generation numbers indicate that a part of the retained fertility of the women in question will remain unperformed. However, this is the situation typical for most countries that undergo the second demographic transition.

The other changes of the reproduction behaviour of the inhabitants of the Czech Republic after 1989 are significant reduction of the abortions, particularly the induced abortions, to roughly one third of the numbers early in the 1990s. The root cause of the drop could be seen in availability of the new contraception methods and in change to the political and economic conditions that brought the extension of the new system of values in the society. When looking at the curves of the abortion level by age, higher intensity of the abortions is obvious in the Ústí nad Labem Region compared to the Czech Republic. Despite the difference was retained the abortion rate has decreased significantly over the last fifteen years also in the Ústí nad Labem Region. The common feature with respect to changes to the abortion rate structure is reduction of the number of abortions in all age groups of women, reduction of the abortion rate of single, married, and divorced women, and drop in the number of induced abortions in all orders (absolutely most abortions in the first and second order).

As far as the changes to general intensity of marriage rate and its structure in the 1990s and early in the 21st century, the relatively significant change is the increased age at the first marriage that is related to shift in the maximum marriage rate intensity from the age group 20-24 years to the age group 25-29 years. The number of divorced official marriages per 1000 inhabitants is higher in the Ústí nad Labem Region with a single exception. The exception is 1999 where gross divorce rate in the Ústí nad Labem Region dropped (2.275 per mil) under the value of the Czech Republic (2.3006 per mil). This was caused by almost halved reduction of the number of settled divorce applications in 1999 compared to 1998 in the Ústí nad Labem Region in relation with adoption of the amendment of the family act, and reduced number of the divorce applications settled by the courts. With respect to the divorce rate structure, there are similar changes in the Czech Republic and in the Ústí nad Labem Region. The average age of the divorced spouses is higher, particularly due to higher age of the spouses at the marriage because the divorce rate intensity depends particularly on term of the marriage.

\section{Discussion and conclusions}

The one of the important fields of the study of the demographic ageing is the research of the impact of the demographic ageing on the economic and social development of the society, especially in the field of the economy, pension system, and healthcare. Should the cause of the demographic revolution be given by the combination of many factors, the impact of the demographic development on the social and economic development is also the matter specific for each country in many aspects; for example, it depends on the economic development of the country, the latest economic development, openness of the economy, current trends, legislation in the field of the social security, the level of health and social care, healthcare spending, and more.

The current population growth in the Czech Republic is particularly caused by the positive immigration. The natural growth rate depends particularly on the age group and shifts between the age units, temporary decrease or increase of the number of born children, and slight improvement of the death rate. Accelerated 
process of the population ageing in all regions of the Czech Republic can be expected in the future. From the view of the population trends in the developed regions, the current development of the Ústí nad Labem Region can be evaluated positively despite remaining unflattering position of the Ústí nad Labem Region within the Czech Republic particularly due to the social structure and social profile of the population within the largest cities of the region (Koutský et al. 2010; Raška et al. 2013). However, we can assume that the change will be slow but growing stronger with the ageing process becoming more powerful and thus influencing the economic performance of the region. It would be therefore necessary to prepare for the process, particularly in the economic and social field, at the level of the regional government, otherwise the demographic ageing may further restrict the speed of economic and social transition in the region.

\section{Acknowledgements}

This article was completed in frame of grant of the Internal grant agency Jan Evangelista Purkyně University in Ústí nad Labem.

\section{References}

Balej $M$, Anděl J, Oršulák $T$, Raška $P$ (2008) Development of environmental stress in the northwestern part of Czechia: new approaches and methods. Geografie-Sborník ČGS, 113(3): 320-336.

Bremner J, Haub C, Lee M, Mather M, Zuehlke E (2009) Population Bulletin. World Population Highlights: Key Findings From PRB'S 2009 World Population Data Sheet. Population Reference Bureau, Vol. 64, No. 3, Washington, DC, USA.

CZSO (2014a) Demografická príručka 2013. www.czso.cz

CZSO (2014b) Demografická ročenka ČR 2013. www.czso.cz

CZSO (2014c) Demografická ročenka krajů 2004 až 2013. www.czso.cz

Fiala T, Langhamrová J (2007) Stárnutí populace hrozba pro veřejné zdravotnictví? Demografie 49: 13-23.

Hlaváček P (2013). Economic and Innovation Adaptability of Regions in the Czech Republic.
Liberec Economic Forum, Proceedings of the 11th International Conference, Liberec, 2013, pp. 194203.

Hoff A (2011) Population Ageing in Central and Eastern Europe. Ashgate, Farnham.

Holmerová I, Vaňková H, Jurásková B, Hrnčiariková D (2011) Population Ageing in the Czech Republic. In: Hoff A (ed) Population Ageing in Central and Eastern Europe. Ashgate, Farnham, pp. 79-94.

Kačírek P (2001) Comparison of Selected Characteristics of the Population in Usti $n$. L. Region According to the Results of the 1991 and 2001 Census, Proceedings of the International Workshop "Regional Interests in the Ústí nad Labem Region and their holders". UJEP, Ústí nad Labem, pp. 20- 24.

Kačírek P (2003) Demographic Reproduction in the Usti region, Social and economic development and regional politics in Ústi region in years 2000-2004, (First Election Period of regional Executive Bodies), Proceedings of the 3nd International Conference UJEP Ústí nad Labem, pp. 101-110.

Koutský J, Rumpel P, Slach O, Bednář P (2010) Reimaging of industrial cities in Czech Republic: selected drivers of chase. In: The regeneration of image in old industrial regions: agents of change and changing agents. Cuvillier Verlag, pp. 89-114.

Lesthaeghe $R$, van de Kaa DJ (1986) Twee demografische transitioes. In: van de Kaa, Lesthaege R (eds) Bevolking: groei en krimp. Van Loghum Slaterus, Deventer, pp. 9-24.

Muenz R (2007) Aging and demographic change in European societies: Main trends and alternative policy options. Washington, DC: Hamburg Institute for International Economics/World Bank.

Pavlík Z (2004) Nejvýznamnější tendence světového populačního vývoje. Demografie 46: 230-234.

Pavlík Z (2007). Současná demografická situace světa a možné perspektivy. Praha (working paper).

Rabušic L (1995) Česká společnost stárne. Masarykova univerzita v Brně, Georgetown.

Raška P, Balej M, Anděl J, Koutský J, Pauš J (2013) Urban environment of selected cities in the Czech Republic between shrinkage and rising bubble: long-term trends and relation to living conditions. ERSA Congress Proceedings, Palermo.

Rychtaříková J (2006) Perspektiva seniorů v České republice a ve vybraných zemích EU. Demografie 48: 252-256. 
Sobotka T (2008) The diverse faces of the Second Demographic Transition in Europe. Dem,ographic Research 19(1): 171-224.

Steinführer A, Haase A (2007) Demographic change as a future challenge for cities in East Central Europe. Geografiska Annaler: Series B, Human Geography 89(2): 183-195.

Turok I, Mykhnenko V (2007) The trajectories of European cities, 1960-2005. Cities 24(3): 165-182

United Nations (2015) World Population Prospects: The 2012 Revision Population Database. Population Division of the Department of Economic and Social Affairs of the United Nations Secretariat.

Van de Kaa DJ (1987) Europe's second demographic transition. Population Bulletin 42(1): 59.
Walker A, Maltby T (2012) Active ageing: A strategic policy solution to demographic ageing in the European Union. International Journal of Social Welfare 21(S1): S117-S130.

Warnes AM (1993) Demographic ageing: trends and policy responses. In: Noin D, Woods R (eds) The changing population of Europe. Cambridge, Massachusetts/Oxford, England, Blackwell, pp. 8299. 